Article

\title{
Digital Transformation and Convergence toward the 2030 Agenda's Sustainability Development Goals: Evidence from Italian Listed Firms
}

\author{
Renato Camodeca (D) and Alex Almici *(D) \\ Department of Economics and Management, Università degli Studi di Brescia, 25121 Brescia, Italy; \\ renato.camodeca@unibs.it \\ * Correspondence: alex.almici@unibs.it
}

check for updates

Citation: Camodeca, R.; Almici, A.

Digital Transformation and

Convergence toward the 2030

Agenda's Sustainability Development Goals: Evidence from Italian Listed Firms. Sustainability 2021, 13, 11831. https://doi.org/10.3390/su132111831

Academic Editor: Antonella Petrillo

Received: 20 September 2021

Accepted: 22 October 2021

Published: 26 October 2021

Publisher's Note: MDPI stays neutral with regard to jurisdictional claims in published maps and institutional affiliations.

Copyright: (C) 2021 by the authors Licensee MDPI, Basel, Switzerland. This article is an open access article distributed under the terms and conditions of the Creative Commons Attribution (CC BY) license (https:/ / creativecommons.org/licenses/by/ $4.0 /)$.

\begin{abstract}
The United Nations 2030 Agenda has emphasized the potential of digital technology to enhance sustainability performance, assuming that digital transformation can enable firms' convergence toward the Sustainable Development Goals. Despite this, the literature is unclear regarding whether there is a positive relationship between digitalization and sustainability, as the effects of digital transformation are controversial. The main goal of this study was to assess the hypothesis that digital technology contributes to the achievement of Sustainable Development Goals within the UN 2030 Agenda. To test this hypothesis, a textual analysis was performed to assess Italian firms' digitalization efforts; the obtained results were then related to the selected firms' ESG scores using a regression analysis. The analysis focused on Italian FTSE MIB listed firms for the period 2016-2019. The findings show a positive relation between digitalization and Sustainable Development Goals, highlighting the relevance of digital technology in implementing the sustainability agenda.
\end{abstract}

Keywords: digital transformation; sustainable development goals; digital technologies; agenda 2030

\section{Introduction}

The Agenda 2030's Sustainable Development Goals (SDGs), which were agreed upon by the United Nations in September 2015, emphasize the role of digital technology in the enhancement of sustainability [1]. The SDGs consist of "a plan of action for people, planet and prosperity" formulated to "shift the world onto a sustainable and resilient path" [2]; in this context, digital transformation has the potential to enable the achievement of sustainable conditions.

The relation between digitalization and sustainability, which has been recently addressed [3-9], sometimes raises doubts regarding the potential positive contributions of digitalization toward achieving the Sustainable Development Goals [4,10-13]. Though most scholars agree that digital transformation can be an effective tool in creating sustainability $[9,14-16]$, some studies have shown that the effects of digital transformation on sustainability are unclear $[8,17]$. For example, Beier et al. argued that "it remains unclear whether the digital transformation of the economy can be reconciled with the goals of sustainable development" [12]. Similarly, Brenner et al. stated: "Although digitalization offers new pathways and (unseen) possibilities, its potential to achieve or impede sustainability of ecological, economic, and social human systems remains unclear" [5].

In general, the relationship between digitalization and sustainability is a controversial issue that must be investigated further in order to assess whether digital transformation can actually help firms to achieve the SDGs.

In light of this critical research gap, this study aimed to assess firms to test the following hypothesis:

Hypothesis 1 (H1). Digital technology contributes to the achievement of the SDGs. 
In order to test this hypothesis, a linear multiple regression analysis was carried out with reference to Italian companies listed on the Financial Times Milan Stock Exchange Index (FTSE MIB), the primary benchmark index for Italian equity markets, as it includes approximately $80 \%$ of domestic market capitalization.

This study sheds light on whether digital technologies implemented by firms can be used to achieve the Sustainable Development Goals listed in the UN 2030 Agenda. To test the above hypothesis, a textual analysis was performed to assess Italian firms' digital efforts. The results were then compared to the selected firms' environmental, social, and governance (ESG) scores using a regression analysis. The ESG scores identify key sustainability performance indicators referring to three main pillars: environmental, concerning the firm's ability to reduce its impact on the ecosystem; social, concerning the community's well-being; and corporate governance, measuring the transparency and ethics of corporate governance body behavior.

This paper helps to bridge the research gap for three main reasons. First, its methodology (a linear multiple regression model) is different from those used in previous studies $[6,7,18,19]$; the link between sustainability and digitalization has traditionally been addressed using qualitative analysis. Second, it assesses the relationship between digital transformation and the SDGs. Finally, the research sample is made up of Italian firms, which have not previously been examined $[7,20]$.

This study's findings underline a positive relationship between a firm's digital transformation and its orientation toward the Sustainable Development Goals; the empirical results show an increasing transition in Italian firms toward meeting the SDGs during 2016-2019. This convergence process is positively affected by the firms' increasing adoption of the most innovative digital technologies, which were seen to enhance their performance economically and otherwise. The findings also show how the national Industry 4.0 plan plays a relevant role, as it encourages the digitalization process by introducing specific incentives, primarily fiscal ones.

This paper is organized as follows: the Section 2 includes the theoretical framework and the literature review, the Section 3 focuses on the methodology, the Section 4 presents the main research findings, the Sections 5 and 6 provide a discussion and conclusions, respectively.

\section{Digital Technology and Sustainable Development Goals}

Over the last few years, the idea of sustainability has become closely intertwined with that of digitalization, giving increasing relevance to technology as a tool for improving global well-being [1,2]. Indeed, since 2016, the United Nations has been working on an international agenda for sustainable development by investing in technology as a relevant driver for achieving specific goals by 2030. More recently, the European Commission has underlined the role of digital technology within the formulation of a new European growth strategy (the so-called Green Deal) aimed at creating a society with zero environmental impact by 2050 [21]. The 2030 Agenda continued the process started by the Millennium Development Goals, which were operational from 2000 until 2015, by selecting 17 Sustainable Development Goals, 169 associated targets, and 232 indicators.

The SDGs were chosen based on the three pillars of the traditional definition of sustainability: social, environmental, and economic [22-24]. The economic pillar is, of course, about financial and economic performance, the social pillar is related to tackling inequalities and ensuring inclusion and accessibility of services, and the environmental pillar is related to protecting the biosphere from carbon emissions and global warming [25-27]. Kuzma et al. stated that the "social dimension is concerned with the social impacts of innovation on human communities inside and outside the organizations. [...] The environmental dimension is concerned with environmental impacts from the use of natural resources and pollutant emissions. [...] The economic dimension is concerned with economic efficiency, without which they would not perpetuate themselves" [28]. Similarly, the World Commission on Environment and Development defines sustainability as "de- 
velopment that meets the needs of the present without compromising the ability of future generations to meet their own needs" [22].

According to United Nations and the Organisation for Economic Co-operation and Development (OECD), achieving the Sustainable Development Goals can be accomplished by the widespread use of digital technologies, which have become essential tools for firms' activities no matter the sector in which they operate $[29,30]$.

The 2030 Agenda identifies digital technologies as potential tools for achievement of the Sustainable Development Goals. In this regard, Seel et al. argued that "digital technologies in the form of e-health services, robotics, or emission reduction solutions could help individuals, organizations, and nations achieve a more sustainable planet in light of the sustainable development goals" [9].

Nambisan identified digital technology as the combination of three distinct components: digital artifacts, digital infrastructure, and digital platforms [31]. Digital artifacts are digital components of a new product that provide specific value to users [32,33], while digital infrastructure is a tool that enables communication [34,35]. Digital platforms are shared sets of services hosting complementary offerings; they include, for example, Apple's iOS and Mozilla's Firefox browser [36].

Lanzolla et al. [37] classified digital technology into four main groups: efficiency technology (e.g., cloud), connectivity technology (e.g., the Internet of Things), trust disintermediation technology (e.g., blockchain), and automation technology (e.g., big data).

The technology that is the most suitable for supporting the transition to sustainability includes the Internet of Things (IoT), big data analytics, blockchain, artificial intelligence and machine learning, cloud, 5G Internet, and virtual reality systems [38-45].

Digital technologies are suitable for producing widespread effects involving all aspects of sustainable development conditions, including global productivity, equality and inclusion, and environmental protection, concurrently.

Digital technologies enable achievement of the SDGs by improving the ability to accomplish the following: protect the ecosystem by limiting the consumption of precious resources and the production of related waste and emissions [6,46,47]; ensure access to fundamental services for everyone by reducing inequalities and enhancing human health, as well as the whole food chain [48]; produce economic benefits as a result of higher productivity; innovate the supply chain based on a customer-centric approach; reduce general costs due to decreased use of non-renewable energies; and introduce circular manufacturing processes.

In terms of the environmental pillar, digital technologies offer an effective method of protecting the ecosystem by reducing emissions, ensuring resilience to natural hazards, and minimizing the effects on climate change in any sector (agriculture, industry, and manufacturing). Digitalization supports low-carbon energy systems that are primarily based on renewable energy and energy efficiency, which produce positive effects in terms of climate change and reduced pollution of all kinds.

The social pillar can benefit from digital transformation in terms of wide access to fundamental services and goods according to inclusion and equity conditions, ensuring, for example, food, health, water, and energy services for populations through low-carbon and circular economy systems.

Finally, with reference to the economic pillar, digital technologies allow firms to innovate their manufacturing processes, enabling increased efficiency and reduced emissions.

Specifically, the digitalization process can promote the convergence toward the SDGs by enabling [49] the following:

- Connection and communication between people

- Monitoring of the world's activities and ecosystems

- Analysis of information and the organization of processes and resources

- Improvement of human capabilities

According to Deloitte et al., "of the 169 SDG targets, 103 are directly influenced by these technologies, with established examples of deployment that provide insight into their 
potential to make an impact. Analysis of 20 targets and their indicators across the SDGs shows that the expected deployment of existing digital technologies will, on average, help accelerate progress by $22 \%$ and mitigate downward trends by $23 \%$ " [49].

This highlights the close relationship between sustainability and digital transformation, which has been widely addressed by scholars [7,50-52].

According to mainstream studies, digital transformation is a dynamic process through which digital technologies enhance firm performance with innovative business [53-55]. In general, digital transformation can be defined as a transition from the analogue to the digital age [56,57], leading firms to general improvement by managing change in a successful manner using digital technologies [53,55,58,59].

Despite this knowledge, the relationship between digital transformation and achieving the Sustainable Development Goals has only recently been addressed $[7,8,18,19,60-64]$, and some controversies exist regarding social and environmental sustainability $[4,10-13]$. Despite the consistent discussion of many potential ways to reach sustainability goals [65-70], few recent studies have linked digital transformation to the sustainability paradigm, particularly in terms of the 2030 Agenda. Indeed, even though some scholars have identified digitalization as one of the most promising methods for achieving sustainability $[9,14-16]$, its actual effects on sustainability remain uncertain. In fact, it is not clear whether and to what extent digital technology can contribute to the achievement of the Sustainable Development Goals, as some scholars see potential threats to sustainability in the coming digital era [10-12]. In general, it is unclear whether digital transformation can be reconciled with the Sustainable Development Goals [8].

In this regard, Fukuda-Parr et al. underline how the increasing relevance of big data and other nontraditional sources of data are "altering data production, dissemination and use, and fundamentally altering the epistemology of information and knowledge" [17]. Similarly, Scholz et al. identified the so-called "unintended side effects of the digital transition", explaining how digitalization may have negative effects on sustainability, especially in terms of the social pillar (Internet addiction, information manipulation, etc.) [10]. Goralski et al. used case-study methodology to assess the impact of artificial intelligence on sustainability on the Sustainable Development Goals [13]. The authors argued that "AI can be a powerful enabler of the global effort to promote economic development and at the same time sustainably address the impact of our production and consumption on our societies, governance systems, and the environment", though they also noted, "AI is a double-edged sword. It can come with multifaceted pitfalls and complex problems that must be rigorously studied and managed to contain its negative and unintended consequences" [13].

Similarly, other scholars have raised doubt regarding the idea that digital transformation can contribute to sustainability, especially in terms of the social and environmental pillars [10-12]. Beir et al. underlined how an increasingly digitalized economy can hamper ecosystems, as some digital technologies are energy-intensive, produce a large carbon footprint, have limited recycling potential, and are primarily sourced from developing countries [12]. They also argued that "despite efficiency gains, growing standards of production and consumption as a result of economic development have led to higher absolute environmental burdens (e.g., $\mathrm{CO}_{2}$ emissions) in every country, it is questionable whether digitalization can help to reverse this trend". Similarly, Kuntsman et al. [11] introduced the expression "unsustainable digital sustainability", arguing that "the materiality of digital communication inflicts substantial environmental damage: the extraction of resources needed to produce digital devices; the toxicity of e-waste; and the rapidly increasing energy demands required to sustain data generated by digital communication". Issues of environmental sustainability were also raised by Akande et al., who explained that there is no direct relation between digitalization and sustainable development; that study showed that a city can be smart but not sustainable and vice versa [4].

Other studies, however, have shown a positive relation between digitalization and the SDGs. Tjoa et al. identified information and communication technology (ICT) as an enabler to achieve the SDGs, pointing out its potential in terms of more efficient resource 
usage, education, and business operations [19]. Similarly, Vinuesa et al. argued that artificial intelligence can contribute to achieving the majority of targets associated with the SDGs by distinguishing between social, economic, and environmental outcomes [64]. Kostoska et al. provided a new ICT framework for addressing sustainability, arguing that digital technologies can enable its achievement [18]. In this context, other scholars have focused on specific geographical areas, such as the four countries of the Visegrad Group, by using specific indicators in order to assess firms' digital transformation efforts and the effects on achieving the SDGs [7] as well as the effects of digital transformation on localization as a key factor in their achievement [60].

The relationship between digital transformation and the SDGs is a critical issue and has been addressed in few studies, though attention has been focused on the opportunities that digitalization provides in order to make a given business sustainable. In this context, El Hilali et al. underlined how customers, data, and innovation, the key digital transformation drivers, affect the adoption of sustainable behaviors [20]. In particular, the authors argued that achieving sustainability in the digital era should focus on three main variables: customer centricity, data analytics capability, and business model innovation. Conversely, other authors focused on either the effects of smart technologies on sustainable business models [71-76] or on how the leading firms in the digital industry have addressed the issue of sustainable development [63].

In this context, several scholars have carried out empirical analyses aimed at assessing whether specific digital technologies can actually improve sustainability conditions; the most explored field in this regard is the environmental one, where digital technologies (especially artificial intelligence) are used to safeguard the ecosystem in specific projects (e.g., smart water management system, plant village) by, for example, identifying waterborne diseases [13]. Similarly, food system traceability and the certification of production processes can be conducted using big data analytics and blockchain. In the social context, some studies have investigated the role of digital technologies in developing countries' education systems [77].

These studies underline that significant effort is still required to reduce the gap in the literature regarding the contribution of digital transformation to the Sustainable Development Goals; more investigation into whether digital transformation can actually enable the achievement of the SDGs is required. In terms of our study, the link between digital transformation and achieving the SDGs has not been empirically explored using statistical tools in the Italian context.

\section{Methodology}

\subsection{Sample Selection}

This study is based on a sample of 40 Italian FTSE MIB listed firms from 2016 to 2019 with 160 observations; 2020 was not considered because the ESG data were not yet available at the time of analysis. This time period was chosen because 2016 marks the starting point of the 2030 Agenda, which was agreed upon on 25 September 2015.

We focused on the FTSE-MIB because it includes the most capitalized Italian firms, covering approximately $80 \%$ of total Italian market capitalization (Table 1).

Table 1. Research sample.

\begin{tabular}{cc}
\hline Economic Sector & Number of Firms \\
\hline Utilities & 5 \\
Healthcare & 3 \\
Industrial & 5 \\
Financial & 14 \\
Basic materials & 1 \\
Consumer staples & 1 \\
Energy & 3 \\
\hline
\end{tabular}


Table 1. Cont.

\begin{tabular}{cc}
\hline Economic Sector & Number of Firms \\
\hline Consumer discretionary & 5 \\
Communication services & 2 \\
Information technology & 1 \\
Total & 40 \\
\hline
\end{tabular}

\subsection{Measurement of the Dependent Variable}

The dependent variable (the SDGs) indicates the firm's sustainability in terms of its orientation toward the Sustainable Development Goals; this variable is represented by ESG scores from 2016-2019, which were retrieved from the Refinitiv Eikon database.

The data quality and credibility of the Eikon database have been confirmed in academic research over the past few years [78-80]; the detail and depth of these data reduce selection bias and ensure consistency with other standard ESG databases [81,82].

Specifically, the ESG scores retrieved from the Refinitiv Eikon database are calculated according to a percentile-based methodology that captures over 450 firm-level ESG indicators. These scores are based on an integrated analysis of the environmental, social, and governance performance of firms listed on international stock exchanges; these firms cover more than $80 \%$ of global market capitalization. The performance of a firm demonstrates the extent of its convergence toward sustainability. Indeed, these data define a firm's sustainability performance and, overall, its orientation toward the Sustainable Development Goals. To this end, attention was focused on the SDGs that are mostly involved in the digital transformation process (Table 2).

Table 2. ESG performance and Sustainable Development Goals.

\begin{tabular}{|c|c|c|}
\hline Sustainability Pillar & ESG Scoring Measures & Sustainable Development Goals \\
\hline \multirow{4}{*}{ Environmental } & $\begin{array}{c}\text { Water efficiency policy } \\
\text { Water efficiency targeted } \\
\text { Total water use/million in revenue } \\
\text { Water recycled } \\
\text { Total water withdrawal } \\
\text { Water pollutant emissions } \\
\text { Water technologies }\end{array}$ & $\begin{array}{c}\text { SDG 6: Clean water and sanitation } \\
\text { Ensure availability and sustainability management of } \\
\text { water and sanitation for all (e.g., by smart } \\
\text { water management) }\end{array}$ \\
\hline & $\begin{array}{l}\text { Environment management team } \\
\text { Environment management training } \\
\text { Emissions policy }\end{array}$ & $\begin{array}{l}\text { SDG 13: Climate action } \\
\text { Take urgent action to combat climate change and its } \\
\text { impacts (e.g., by transitioning to } \\
100 \% \text { renewable energy) }\end{array}$ \\
\hline & $\begin{array}{l}\text { Toxic chemical reduction } \\
\text { Accidental spills }\end{array}$ & $\begin{array}{c}\text { SDG 14: Life below water } \\
\text { Conserve the oceans, seas, and marine resources for } \\
\text { sustainable development (e.g., by digital technologies } \\
\text { monitoring marine resources) }\end{array}$ \\
\hline & $\begin{array}{l}\text { Environmental supply chain policy } \\
\text { Environmental materials sourcing } \\
\text { Toxic chemical reduction } \\
\text { Coal production } \\
\text { Biodiversity impact reduction } \\
\text { Total waste }\end{array}$ & $\begin{array}{l}\text { SDG 15: Life on land } \\
\text { Protect, restore, and promote the sustainable use of } \\
\text { terrestrial ecosystems and sustainably manage forests, } \\
\text { combat diversification, halt and reverse land } \\
\text { degradation, and halt biodiversity loss (e.g., by } \\
\text { artificial intelligence and cloud enabling more } \\
\text { sustainable management of forests) }\end{array}$ \\
\hline
\end{tabular}


Table 2. Cont.

\begin{tabular}{|c|c|c|}
\hline Sustainability Pillar & ESG Scoring Measures & Sustainable Development Goals \\
\hline \multirow{40}{*}{ Social } & Community lending and investments & SDG 1: No poverty \\
\hline & Donations & End poverty in all its forms, everywhere (e.g., by \\
\hline & Political contributions & improving farming practices in poor countries through \\
\hline & Accessible product pricing & machine learning prediction of climate risk exposure) \\
\hline & & SDG 10: Reduced inequalities \\
\hline & & Reduce inequality within and among countries \\
\hline & & $\begin{array}{l}\text { (e.g., by using digital technologies supporting } \\
\text { productivity in poor countries) }\end{array}$ \\
\hline & & SDG 2: Zero hunger \\
\hline & Product discounts for omoroing countrioc & End hunger, achieve food security and improved \\
\hline & Product discounts for emerging countries & $\begin{array}{c}\text { nutrition, and promote sustainable agriculture (e.g., by } \\
\text { smart agriculture) }\end{array}$ \\
\hline & & SDG 3: Good health and well-being \\
\hline & & Ensure healthy lives and promote well-being for all at \\
\hline & Health and safety policy & all ages (e.g., by ensuring basic digital access for those \\
\hline & & $\begin{array}{c}\text { more vulnerable and by using artificial intelligence } \\
\text { and machine learning) }\end{array}$ \\
\hline & & SDG 4: Quality education \\
\hline & Child lahor nolicy & Ensure inclusive and equitable quality education and \\
\hline & & $\begin{array}{c}\text { promote lifelong learning opportunities for all } \\
\text { (e.g., by e-learning) }\end{array}$ \\
\hline & Diversity and opportunity policy & \\
\hline & Women employees & SDG 5: Gender equality \\
\hline & Women managers & Achieve gender equality and empower all women and \\
\hline & Gender pay gap percentage & girls (e.g., by digital access enabling smart working) \\
\hline & Energy efficiency policy & \\
\hline & Energy efficiency targets & \\
\hline & Total energy use/million in revenue & SDG 7: Affordable and clean energy \\
\hline & Total energy use & Ensure access to affordable, reliable, sustainable, and \\
\hline & Energy purchased directly & modern energy for all (e.g., by smart energy) \\
\hline & Indirect energy use & \\
\hline & Renewable energy use ratio & \\
\hline & Green buildings & \\
\hline & Eco-design products & SDG 1: Sustainable cities and communities \\
\hline & Percentage of green products & Make cities and human settlements inclusive, safe, \\
\hline & Hybrid vehicles & resilient and sustainable (e g by smart cities) \\
\hline & Sustainable building products & \\
\hline & Real estate sustainability certifications & \\
\hline & & SDG 16: Peace, justice, and strong institutions \\
\hline & Human rights policy & Promote peaceful and inclusive societies for \\
\hline & Ethical trading initiative & sustainable development, provide access to justice for \\
\hline & Community involvement policy & all, and build effective, accountable, and inclusive \\
\hline & Fair trade policy & institutions at all levels (e.g., by using digital \\
\hline & & eal with crime) \\
\hline
\end{tabular}


Table 2. Cont.

\begin{tabular}{|c|c|c|}
\hline Sustainability Pillar & ESG Scoring Measures & Sustainable Development Goals \\
\hline \multirow{3}{*}{ Economic } & $\begin{array}{l}\text { Diversity and opportunity policy } \\
\text { Employee satisfaction } \\
\text { Salaries and wages from CSR reporting } \\
\text { Net employment creation } \\
\text { Employees with disabilities }\end{array}$ & $\begin{array}{l}\text { SDG 8: Decent work and economic growth } \\
\text { Promote sustained, inclusive and sustainable } \\
\text { economic growth, full and productive employment } \\
\text { and decent work for all (e.g., by smart working). }\end{array}$ \\
\hline & Total R\&D/million in revenue & $\begin{array}{l}\text { SDG 9: Industry, innovation, and infrastructure } \\
\text { Build resilient infrastructure, promote inclusive and } \\
\text { sustainable industrialization, and foster innovation } \\
\text { (e.g., by increasing productivity while reducing } \\
\text { emissions and waste) }\end{array}$ \\
\hline & $\begin{array}{l}\text { Responsible marketing policy } \\
\text { Product responsibility monitoring } \\
\text { Healthy food and products } \\
\text { Retailing responsibility }\end{array}$ & $\begin{array}{l}\text { SDG 12: Responsible consumption and production } \\
\text { Ensure sustainable consumption and production } \\
\text { patterns (e.g., by ensuring transparency in production } \\
\text { and supply chains through blockchain technology) }\end{array}$ \\
\hline
\end{tabular}

\subsection{Measurement of Independent and Control Variables}

This research was aimed at determining whether there is a relationship between firms' digital transformation and the SDGs.

Specifically, the hypothesis to be tested is as follows:

Hypothesis 2 (H2). Digital technology contributes to the achievement of the SDGs.

Digital transformation is identified using two independent variables: a firm's digitalization efforts and its interest in investments promoted by the national Industry 4.0 plan $[83,84]$.

\subsubsection{Digitalization Efforts}

A firm's digitalization effort (DE) was used as an explanatory variable in determining whether there is a relationship between digital transformation and the Sustainable Development Goals; indeed, the link between a firm's digital efforts and its impact on sustainable behaviors as per the SDGs is the main focus of interest of this study.

To the best of our knowledge, no empirical studies have examined the above-stated relation using multiple linear regression; some studies have used statistical tools to address the topic of digitalization, but focused on value relevance [83,84].

In order to obtain the data to assess firms' digitalization efforts, a textual analysis was carried out based on annual non-financial reports (specifically, the sustainability report, the integrated report, and the non-financial statement pursuant to Italian Legislative Decree 254/2016). Attention was focused on the non-financial report, as the dependent variable is represented by a firm's orientation toward SDGs as determined by ESG scores. All analyzed reports were downloaded from the selected firms' websites, mainly by accessing the "Investor relations" section.

Textual analysis is particularly suitable for analyzing firms operating in different industries, allowing inferential analysis of their decisions [85]. The textual analysis performed in this paper builds on a previous empirical study carried out by Hossnofsky et al. [83], who formulated a "digitalization dictionary" that includes keywords that specific survey participants (professors and $\mathrm{PhD}$, graduate, and undergraduate students) expressly related to digitalization. The selected words were then divided into three main groups: app, artificial intelligence, and artificial reality.

The digitalization dictionary was used to carry out content analysis based on the annual non-financial reports of Italian FTSE MIB listed firms using Linguistic Inquiry Word Count (LIWC), which is a software for digitalized content analysis, in terms of a selected dictionary. 
The logic of the content analysis performed in this study assumes that sentences and words "that are frequently used are cognitively central and reflect what is most on the user's mind" [86].

The above research technique allows for the calculation of an approximate measure of the attention paid by the selected firms to digitalization from 2016 to 2019.

Almost all non-financial reports have been audited, implying acceptable data reliability; thus, even if a sustainability report is not a mandatory disclosure tool, the research findings can be considered reliable in order to explain the selected firms' decisions about digitalization.

In addition, the analysis focused on FTSE MIB listed firms, which covers approximately the $80 \%$ of domestic market capitalization, implying that large firms are more likely to improve the quality of disclosure than smaller ones [87-90].

\subsubsection{Industry 4.0}

The other explanatory variable (IND.4.0) was identified using the firm's interest in investments promoted by the national Industry 4.0 plan for industrial, technological, and digital transformation launched by the Italian Ministry of Economic Development (2017 Italian Budget Law). The plan is aimed at providing tax incentives for investments in goods and technologies that connect physical and digital systems in accordance with the Industry 4.0 model (e.g., hyper-depreciation of tangible operating assets, tax credits for R\&D, a new Sabatini Act, facilitation for SMEs and innovation start-ups). Industry 4.0 encourages the digital integration of manufacturing processes and the supply chain, the enhancement of products and processes using digital devices, and the implementation of systems of analysis based on big data.

The Industry 4.0 plan promotes the use of innovative technologies, helping firms to adapt and digitally transform; this variable is useful for explaining firms' orientation toward the Sustainable Development Goals and related improvements in performance, economically and otherwise.

The extent of the selected firms' interest in Industry 4.0 investments was assessed through a textual analysis of annual non-financial reports using Linguistic Inquiry Word Count software. This analysis was carried out using a specific set of keywords related to the digitalization process promoted through the Industry 4.0 national plan; this set of words was used in addition to the set defined for assessing the "digitalization efforts" variable.

In sum, the IND.4.0 variable indicates a firm's interest in the Industry 4.0 national plan as disclosed in its annual non-financial reports throughout the selected period. The annual non-financial reports (sustainability report, integrated report, and non-financial statement pursuant to Italian Legislative Decree 254/2016) were downloaded from the listed firms' websites ("Investor relations" section).

\subsubsection{Control Variables}

The control variable was defined as a firm's strategic vision in terms of achieving the SDGs (SUST), as shown in Table 3. Considering a specific set of keywords and using Linguistic Inquiry Word Count software, a textual analysis of non-financial reports was carried out in order to assess the extent to which sustainability conditions were translated into strategic goals. This explains the inclination of corporate governance bodies to integrate sustainability into their strategy formulation process, enabling the selection of long-term goals according to all relevant pillars (environmental, social, and economic) to enhance firm performance. 
Table 3. Dependent and independent variables.

\begin{tabular}{|c|c|c|}
\hline Full Variable Name & Abbreviated Variable Name & Measurement \\
\hline \multicolumn{3}{|l|}{ Dependent variable } \\
\hline $\begin{array}{l}\text { 1. } 2030 \text { Agenda's Sustainable } \\
\text { Development Goals }\end{array}$ & SDGs & $\begin{array}{l}\text { ESG scores retrieved from } \\
\text { Refinitiv Eikon database }\end{array}$ \\
\hline Independent variables & & \\
\hline $\begin{array}{l}\text { 2. Firm's digitalization efforts } \\
\text { 3. Industry } 4.0\end{array}$ & $\begin{array}{c}\text { DE } \\
\text { IND.4.0 }\end{array}$ & $\begin{array}{l}\text { Text analysis of non-financial } \\
\text { annual reports }\end{array}$ \\
\hline $\begin{array}{l}\text { Control variable } \\
\text { 4. Sustainable strategic vision }\end{array}$ & SUST & $\begin{array}{l}\text { Text analysis of non-financial } \\
\text { annual reports }\end{array}$ \\
\hline
\end{tabular}

\subsection{Data Analysis}

The contribution of digital transformation to sustainability performance was tested using a multiple regression model (Model); the related variables are shown in Table 3.

$$
\mathrm{SDG} s=s s_{0}+s s_{1} \mathrm{DE}+s s_{2} \mathrm{IND} .4 .0+s s_{3} \mathrm{SUST}+\varepsilon(\text { Model })
$$

This formula allows us to assess whether there is a positive relationship between digital transformation (identified by the independent variables shown in Table 3) and the Sustainable Development Goals (dependent variable).

The analysis was performed using IBM SPSS Statistics software, version 25.

\section{Results}

\subsection{Descriptive Analysis and Correlation}

As shown in Table 4, the descriptive statistics include mean, standard deviation, minimum, and maximum. Means and standard deviations were calculated in order to summarize the observed data; according to Field, means represent a summary of the data and standard deviations explain how well the means represent the data [81].

Table 4. Summary statistics for independent and control variables.

\begin{tabular}{lcccc}
\hline \multicolumn{1}{c}{ Variable } & Mean & SD & Minimum & Maximum \\
\hline 1. SDGs & 57.45 & 17.15 & 21.98 & 91.22 \\
\hline 2. Firm's digital effort & 0.0384 & 0.0321 & 0.0022 & 0,1733 \\
\hline 3. Industry 4.0 & 0.0160 & 0.0039 & 0.0100 & 0.0300 \\
\hline 4. Sustainable strategic vision & 0.2236 & 0.1490 & 0.1900 & 0.4575 \\
\hline
\end{tabular}

The mean value of the dependent variable was 57.45, while the mean of independent and control variables was $0.0384,0.0160$, and 0.2236 , respectively; these figures reveal small to medium standard deviations as compared to the means, indicating that the data points are close to the means [91]. Thus, these data indicate a fair reproduction of reality.

Table 5 shows pair-wise Pearson correlations with regard to the dependent and independent variables; the correlations between a firm's digitalization efforts and the Industry 4.0 model with the SDGs are positive and significant, suggesting that firms with higher levels of digitalization tend to experience enhanced sustainability.

In terms of the independent variables, the correlation coefficients suggest that multicollinearity is unlikely, as they assume values far from either 1 or -1 . The low multicollinearity is also supported by the tolerance (TOL) and variance inflation factor (VIF) measures; the coefficients are close to 1 and less than 5, respectively [92]. 
Table 5. Correlation analysis.

\begin{tabular}{lcccc}
\hline \multicolumn{1}{c}{ Variable } & SDGs & Firm's Digital Effort & Industry 4.0 & Sustainable Strategic Vision \\
\hline 1. SDGs & 1.00 & & & \\
\hline 2. Firm's digital effort & $0.44^{* *}$ & 1.00 & 1.00 & 1.00 \\
\hline 3. Industry 4.0 & $0.38^{*}$ & -0.07 & 0.06 & \\
\hline 4. Sustainable strategic vision & $0.54^{* *}$ & $0.43^{* *}$ & \\
\hline
\end{tabular}

Note: ${ }^{*} p<0.05,{ }^{* *} p<0.01$.

\subsection{Dependent Variable Normality Tests}

The Kolmogorov-Smirnov and Shapiro-Wilk tests were performed to test the SDGs' statistical normality [93-96]. The results of both tests were statistically non-significant ( $p=0.20$ and $p=0.55)$, thus the null hypothesis was accepted, demonstrating that the observed data were normally distributed (Table 6).

Table 6. SDG normality tests.

\begin{tabular}{cccc}
\hline \multicolumn{2}{c}{ Kolmogorov-Smirnov Test } & \multicolumn{2}{c}{ Shapiro-Wilk Test } \\
\hline Statistics t & $p$ & Statistics t & $p$ \\
\hline 0.082 & $0.200^{*}$ & 0.976 & $0.550 *$ \\
\hline Note: $^{*} p>0.05$. & &
\end{tabular}

\subsection{Regression Results}

Table 7 shows the estimation results of the selected model, highlighting the effects of digital efforts and Industry 4.0 on firms' sustainability performance. The overall $\mathrm{R}$-squared is 0.4859 , meaning that this model explains nearly $49 \%$ of the variation in sustainability performance.

Table 7. Main effects of digitalization efforts and Industry 4.0 on SDGs.

\begin{tabular}{cccc}
\hline Variable & Coefficient & Standardized Coefficient & Stat. $\mathbf{t}$ \\
\hline $\mathrm{DE}$ & $160.7802462^{*}$ & 0.316 & 2.21 \\
\hline IND.4.0 & $1642.91920^{* *}$ & 0.380 & 2.99 \\
\hline SUST. & $45.26637101^{* *}$ & 0.380 & \\
\hline Observations & 160 & & \\
\hline $\mathrm{R}^{2}$ overall & 0.4859 & & \\
\hline Number of firms & 40 & &
\end{tabular}

All of the model's coefficients (ß) are positive, meaning that a firm's digital transformation increases its potential to achieve the Sustainable Development Goals. A firm's digital efforts are shown to be positively and significantly ( $B=160.7802462, p=0.033915842)$ related to its sustainability performance (SDGs) as well as the Industry 4.0 national plan ( $(B=1642.91920, p=0.005101007)$. Specifically, all other variables being equal, as a result of the unitary increase of the digitalization effort variable, sustainability performance increased by 160.78 , while as a result of the unitary increase of the Industry 4.0 variable, the dependent variable SDGs increased by 1642.91 . The regression coefficients (B) highlight that these two variables are statistically significant in explaining a firm's orientation toward SDGs as identified by ESG scoring. Considering the standardized coefficients (ß), it is possible to identify the variable that most affects sustainability performance, namely IND.4.0.

These findings support the hypothesis that digital technology contributes to the achievement of 2030 Agenda's Sustainable Development Goals.

As for the control variables, Table 7 reports a positive and significant $(B=45.26637101$, $p=0.008083396)$ relationship between the formulation of a sustainable strategic vision and 
the SDGs. All other variables being equal, the SDGs variable increased by 45.27 as a result of the unitary increase of the control variable.

Indeed, firms that formulate a strategy using sustainability principles are more likely to achieve the Sustainable Development Goals.

When analyzing the above relationship in terms of each selected year (2016-2019), the results show an increasing trend, with a general convergence of Italian firms toward sustainability. The regression coefficients and their related $p$-values increasingly improved as the analysis progressed from 2016 to 2019.

\section{Discussion}

The aim of this paper was to assess the existing relationship between digital technology and achieving the 2030 Agenda's SDGs.

In order to assess this relationship, the analysis was focused on two specific independent variables: the digitalization efforts of Italian listed firms and their interest in investments promoted by the national Industry 4.0 plan for industrial, technological, and digital transformation launched by the Italian Ministry of Economic Development.

The regression analysis highlights these variables' statistical significance ( $p$-values); further, the standardized coefficients indicate a positive relationship between digital transformation and achievement of the SDGs.

These findings confirm the selected hypothesis: digital technology contributes to the achievement of the SDGs. Specifically, an increased level of digitalization indicates improved sustainability performance, demonstrating that digital technology can effectively contribute to the achievement of sustainability conditions agreed upon by the United Nations. Indeed, as explained in Section 2, almost all SDGs can benefit from digital technology, as all the sustainability dimensions (environmental, social, and economic) can be improved by digital transformation. Artificial intelligence, blockchain, data analytics, robotics, the Internet of Things, social media, cloud technology, and digital reality are tools that firms can use to better protect the ecosystem, by reducing waste and emissions through circular economy models; enable sustainable production and consumption models; and reduce inequality and discrimination to ensure fairness, equal opportunities, and wide accessibility to primary services. Besides, digital technology allows firms to obtain and manage increasing quantities of data, whose strategic relevance is highlighted in the digital era. Indeed, using digital technology, firms can collect and use data more easily and take decisions more rapidly, according to the principles of continuous adjustment to changeable conditions. Thus, achieving the SDGs can be enabled by digital transformation, which is both a challenge (e.g., in terms of privacy and cyber-security issues) and a relevant opportunity to change the methods and tools that firms use to carry out their activities, ensuring environmental protection and meeting the community's expectations and the needs of future generations. However, digital transformation can contribute to achieving the SDGs only if firms can manage a trade-off between economic activities, quality of life, and environmental safeguarding according to global responsibility, inclusion, and equal opportunity principles.

In detail, the IND.4.0 variable, explaining the Italian firms' interest in investments promoted by the national Industry 4.0 plan, can strongly affect sustainability performance. The related standardized coefficient (B) is equal to 1642.91920; this indicator underlines the potential impact of Industry 4.0 investments on sustainability performance. Indeed, this plan introduces fiscal incentives for investments aimed at enabling the digital integration of manufacturing processes and the supply chain. The plan is intended to promote sustainable and interconnected innovation in order to ensure integration between ICT and industrial processes. It is clear that this plan can be an effective tool in promoting the digital technology needed to improve the relationship between firms, the environment, and the community. The regression analysis shows that the national Industry 4.0 plan is a great opportunity to promote innovative investments that can increasingly contribute to achieving the SDGs. Thus, this analysis supports the idea that policymakers should extend the plan 
by strengthening the incentives to stimulate convergence toward the SDGs at a national level. This opportunity is particularly relevant in the Italian context, as Italy is one of the Europe's least digitalized countries [97]. At the same time, this study demonstrates that sustainability can be enabled by policymakers' decisions as long as they decide to support digitalization through specific incentives (e.g., fiscal incentives).

Thus, this study supports the idea that a digital transformation could contribute to improve sustainability performance, confirming the mainstream research both theoretically and practically. The majority of scholars consider digitalization as an opportunity to facilitate the achievement of the SDGs; studies that raise doubt about the contribution of digital technology mainly emphasize the environmental and social aspects of sustainability $[4,10-13]$. This paper demonstrates that new technologies can improve sustainability with regard to all relevant dimensions (economic, social, and environmental), thus the benefits of digitalization outweigh the threats and related risks.

In addition, the selected firms' attention to investments in digitalization indicates that the use of new technologies is increasing with opportunities to use them to improve sustainability conditions. Indeed, the regression analysis demonstrates increased improvement of the relationship between digitalization and SDG achievement between 2016 and 2019. These findings represent some positive elements with regard to the Italian digitalization process and the related achievement of SDGs, leading to an optimistic view about reducing the existing digitalization gap between Italy and other European countries.

\section{Conclusions}

Over the last several years, digitalization has become increasingly relevant for firms. Firms have innovated their products and processes, enabling enhanced performance in the long run, using digital technologies [98-104]. Firms have increasingly invested in digital transformation; in the Italian context, this has been partially due to incentives introduced by the national Industry 4.0 plan. Many of these new technologies are particularly helpful in allowing firms to improve their relationships with the ecosystem and the community while enhancing their economic performance.

Indeed, digitalization represents an opportunity for firms to reduce waste and its impact on the environment and to better assess the expectations of all relevant stakeholders in order to satisfy them according to equity, engagement, accessibility, and inclusivity principles. At the same time, these new digital technologies offer an opportunity for firms to improve their profitability through network externalities $[96,105,106]$ and the introduction of new digital servitization business models [107-120].

These observations point out the ways in which digitalization is intertwined with sustainability as specifically identified by the United Nations SDGs; that is, digital technology can be a powerful tool for achieving these goals. However, the assessment of this relationship is controversial in the literature, as some scholars argue that digitalization may hamper the achievement of the SDGs [4,10-13]. However, this study demonstrates that there is a positive relationship between firms' digitalization and sustainability results as identified by ESG scores. Specifically, this study shows an increasing convergence trend from 2016 to 2019 as a result of firms' deeper understanding that sustainability requires an adequate set of innovative tools to ensure ecosystem protection, the inclusion and engagement of all community members, and the enhancement of economic performance simultaneously.

To sum up, our results support the main argument of the study, that a firm's digital transformation is positively related to its sustainability; the results in Section 4 indicate that a firm's investment in digitalization, as disclosed in its annual reports, can support the achievement of the SDGs.

Thus, our findings demonstrate a positive relationship between digital transformation and the SDGs; this evidence is relevant for policymakers, regulators, and financial institutions, all of which should encourage investments in digital technologies with a clear focus on sustainability, as well as management professionals, who should promote digitalization in order to improve firm performance. In order to enhance the positive impact of digitaliza- 
tion on sustainability performance, digital transformation should be conducted with a clear understanding of the specific implications and concerns with regard to all stakeholders and sustainability pillars.

Indeed, this study has several relevant implications, in terms of both policy and management. First, policymakers should ensure that effective measures promoting technological investments with specific incentives are introduced (e.g., the national Industry 4.0 plan). Second, international cooperation should be strengthened, by sharing with emerging countries the most innovative tools and related know-how. Third, there should be a clear focus on identifying and assessing the conditions that hamper the integration of digital technologies and SDGs. Fourth, policymakers should promote coordination between international policies aimed at supporting a digital transition, in order to provide the same opportunities to firms.

In terms of managerial implications, this study points out the need to introduce specific key performance indicators (KPIs) to enable an assessment of the contribution of digital technology to sustainability performance. Similarly, firms should revise their organizational structure and internal processes according to the increasing relevance of ICT.

This study is innovative and contributes to the theoretical research in four main ways: the methodology is different from traditional ones, as the literature, as per the authors' understanding, does not include studies that address the relationship between digital transformation and sustainability using regression models; the findings contribute to filling the gap in the literature on assessing the relationship between digitalization and SDGs; and the analysis is focused on listed Italian firms, while previous studies focused on other countries.

However, this study has some limitations. As it focuses on Italian FTSE MIB listed firms, other firms should be explored in order to provide a more complete overview of the relationship between digitalization and sustainability. Future research should also address non-Italian firms in order to conduct international comparisons and provide an assessment of the relation between digitalization and sustainability in a broader context. In order to make such comparisons, digital tools can allow textual analysis even in countries where written and spoken languages differ.

Author Contributions: Conceptualization, R.C.; methodology, A.A.; formal analysis, A.A.; investigation, R.C. and A.A.; data curation, A.A.; writing-original draft preparation, R.C. and A.A.; writing-review and editing, R.C. and A.A.; supervision, R.C. All authors conceived the article and contributed to the manuscript. All authors have read and agreed to the published version of the manuscript.

Funding: This research received no external funding.

Institutional Review Board Statement: Not applicable.

Informed Consent Statement: Not applicable.

Conflicts of Interest: The authors declare no conflict of interest.

\section{References}

1. United Nations. The 2030 Agenda for Sustainable Development; United Nations: Paris, France, 2015.

2. United Nations. Take Action for the Sustainable Development Goals; United Nations: Paris, France, 2020.

3. The Convergence of Digitalization and Sustainability. MIT Sloan Management Review, 17 January 2018. Available online: https:/ / sloanreview.mit.edu/article/the-convergence-of-digitalization-and-sustainability/ (accessed on 2 August 2021).

4. Akande, A.; Cabral, P.; Casteleyn, S. Assessing the Gap between Technology and the Environmental Sustainability of European Cities. Inf. Syst. Front. 2019, 21, 581-604. [CrossRef]

5. Brenner, B.; Hartl, B. The Perceived Relationship between Digitalization and Ecological, Economic, and Social Sustainability. J. Clean. Prod. 2021, 315, 128128. [CrossRef]

6. Feroz, A.K.; Zo, H.; Chiravuri, A. Digital Transformation and Environmental Sustainability: A Review and Research Agenda. Sustainability 2021, 13, 1530. [CrossRef]

7. Esses, D.; Csete, M.; Németh, B. Sustainability and Digital Transformation in the Visegrad Group of Central European Countries. Sustainability 2021, 13, 5833. [CrossRef] 
8. Del Río, C.G.; Fernández, M.C.G.; Colsa, A.U.U. Unleashing the Convergence Amid Digitalization and Sustainability Towards Pursuing the Sustainable Development Goals (SDGs): A holistic review. J. Clean. Prod. 2021, 280, 1-40. [CrossRef]

9. Seele, P.; Lock, I. The Game-Changing Potential of Digitalization for Sustainability: Possibilities, Perils, and Pathways. Sustain. Sci. 2017, 12, 183-185. [CrossRef]

10. Scholz, R.W.; Bartelsman, E.J.; Diefenbach, S.; Franke, L.; Grunwald, A.; Helbing, D.; Hill, R.; Hilty, L.; Höjer, M.; Klauser, S.; et al. Unintended Side Effects of the Digital Transition: European Scientists' Messages from a Proposition-Based Expert Round Table. Sustainability 2018, 10, 2001. [CrossRef]

11. Kuntsman, A.; Rattle, I. Towards a Paradigmatic Shift in Sustainability Studies: A Systematic Review of Peer Reviewed Literature and Future Agenda Setting to Consider Environmental (Un)sustainability of Digital Communication. Environ. Commun. 2019, 13, 567-581. [CrossRef]

12. Beier, G.; Fritzsche, K.; Kunkel, S.; Matthess, M.; Niehoff, S.; Reißig, M.; van Zyl-Bulitta, V. A Green Digitalized Economy? Challenges and Opportunities for Sustainability. Inst. Adv. Sustain. Stud. (IASS) Fact Sheet 2020, 1, 1-10. [CrossRef]

13. Goralski, M.A.; Tan, T.K. Artificial Intelligence and Sustainable Development. Int. J. Manag. Educ. 2020, 18, 1-9. [CrossRef]

14. Gouvea, R.; Kapelianis, D.; Kassicieh, S. Assessing the Nexus of Sustainability and Information \& Communications Technology. Technol. Forecast. Soc. Chang. 2018, 130, 39-44. [CrossRef]

15. Sachs, J.D.; Schmidt-Traub, G.; Mazzucato, M.; Messner, D.; Nakicenovic, N.; Rockström, J. Six Transformations to Achieve the Sustainable Development Goals. Nat. Sustain. 2019, 2, 805-814. [CrossRef]

16. Walker, J.; Pekmezovic, A.; Walker, G. Sustainable Development Goals: Harnessing Business to Achieve the SDGs through Finance, Technology and Law Reform; Wiley: Hoboken, NJ, USA, 2019.

17. Fukuda-Parr, S.; Mcneill, D. Knowledge and Politics in Setting and Measuring the SDG s: Introduction to Special Issue. Glob. Policy 2019, 10, 5-15. [CrossRef]

18. Kostoska, O.; Kocarev, L. A Novel ICT Framework for Sustainable Development Goals. Sustainability 2019, 11, 1961. [CrossRef]

19. The Role of ICT to Achieve the UN Sustainable Development Goals (SDG). Available online: https://link.springer.com/chapter/ 10.1007/978-3-319-44447-5_1 (accessed on 10 October 2021).

20. El Hilali, W.; Addellah, E.M.; Mohammed, A.J.I. Reaching Sustainability During a Digital Transformation: A PLS Approach. Intern. J. Innov. Sci. 2020, 13, 52-79. [CrossRef]

21. European Commission. Communication from the Commission to the European Parliament, the European Council, the Council, the European Economic and Social Committee and the Committee of the Regions. The European Green Deal; European Commission: Brussels, Belgium, 2019.

22. World Commission on Environment and Development. Our Common Future; Oxford University Press: Oxford, UK, 1987.

23. United Nations Environmental Protection Agency. Learn about Sustainability; What Is Sustainability? 2014. Available online: https:/ / www.epa.gov/sustainability (accessed on 2 August 2021).

24. Sustainable Development: Meaning, History, Principles, Pillars, and Implications for Human Action: Literature Review. Available online: https: / / www.tandfonline.com/doi/full/10.1080/23311886.2019.1653531 (accessed on 10 October 2021).

25. D'Amico, E.; Coluccia, D.; Fontana, S.; Solimene, S. Environmental Sustainability: An Empirical Survey on Italian Listed ComPanies. In Knowledge and Management Models for Sustainable Growth. In Proceedings of the 9th International Forum on Knowledge Asset Dynamics, Matera, Italy, 11-13 June 2014; Emerald: Bingley, UK, 2014.

26. Salvioni, D.M.; Almici, A. Circular Economy and Stakeholder Engagement Strategy. Symphonya Emerg. Issues Manag. 2020, 26-44. [CrossRef]

27. Salvioni, D.; Almici, A. Trdoi:itioning Toward a Circular Economy: The Impact of Stakeholder Engagement on Sustainability Culture. Sustainability 2020, 12, 8641. [CrossRef]

28. Kuzma, E.; Padilha, L.S.; Sehnem, S.; Julkovski, D.J.; Roman, D.J. The Relationship Between Innovation and Sustainability: A Meta-Analytic Study. J. Clean. Prod. 2020, 259. [CrossRef]

29. United Nations. Transforming Our World: The 2030 Agenda for Sustainable Development. Resolution Adopted by the General Assembly on 25 September; Department of Economic and Social Affairs: San Francisco, CA, USA, 2015.

30. OECD. The Digitalization of Science, Technology and Innovation; OECD Library: Paris, France, 2020.

31. Nambisan, S. Digital Entrepreneurship: Toward a Digital Technology Perspective of Entrepreneurship. Entrep. Theory Pract. 2017, 41, 1029-1055. [CrossRef]

32. Ekbia, H.R. Digital Artifacts as Quasi-Objects: Qualification, Mediation, and Materiality. J. Am. Soc. Inf. Sci. Technol. 2009, 60, 2554-2566. [CrossRef]

33. Kallinikos, J.; The London School of Economics and Political Science; Aaltonen, A.; Marton, A.; Hanken School of Economics; Copenhagen Business School. The Ambivalent Ontology of Digital Artifacts. MIS Q. 2013, 37, 357-370. [CrossRef]

34. Tilson, D.; Lyytinen, K.; Sørensen, C. Research Commentary-Digital Infrastructures: The Missing IS Research Agenda. Inf. Syst. Res. 2010, 21, 748-759. [CrossRef]

35. Ciborra, C.; Braa, K.; Cordella, A.; Hepsø, V.; Dahlbom, B.; Failla, A.; Hanseth, O.; Liungberg, J.; Monteiro, E. From Control to Drift: The Dynamics of Corporate Information Infrastructures; Oxford University Press: New York, NY, USA, 2001.

36. Tiwana, A.; Konsynski, B.; Bush, A.A. Research Commentary-Platform Evolution: Coevolution of Platform Architecture, Governance, and Environmental Dynamics. Inf. Syst. Res. 2010, 21, 675-687. [CrossRef] 
37. Lanzolla, G.; Lorenz, A.; Miron-Spektor, E.; Shilling, M.; Solinas, G.; Tucci, C. Digital Transformation: What is New if Anything? Acad. Manag. Discov. 2018, 4, 378-387.

38. Lee, H.J. A Review of Value Creating Motive and Business Model in Smart Technology. In Human Centric Technology and Service in Smart Space; Park, Y.H., Jin, Q., Yeo, M.S., Hu, B., Eds.; Springer: Dordrecht, The Netherlands, 2012.

39. Du, W.Y.; Pan, S.L.; Huang, J.S. How a Latecomer Company Used IT to Redeploy Slack Resources. MIS Quart. Exec. 2016, 15, 195-213.

40. Dürr, S.; Wagner, H.-T.; Weitzel, T.; Beimborn, D. Navigating Digital Innovation-The Complementary Effect of Organizational and Knowledge Recombination. In Proceedings of the 13th International Conference on Wirtschaftsinformatik, St Gallen, Switzerland, 12-15 February 2017; AIS Electronic Library: Atlanta, GA, USA, 2017.

41. Petrikina, J.; Krieger, M.; Schirmer, I.; Stoeckler, N.; Saxe, S.; Baldauf, U. Improving the Readiness for Change-Addressing In-Formation Concerns of Internal Stakeholders in the SmartPORT Hamburg. In Proceedings of the Americas Conference of Information Systems, Boston, MA, USA, 10-12 August 2017.

42. Glaser, F. Pervasive Decentralization of Digital Infrastructures: A Framework for Blockchain Enabled System and Use Case Analysis. In Proceedings of the 50th Hawaii International Conference on System Sciences, Waikoloa Beach, HI, USA, 4-7 January 2017.

43. Sebastian, I.M.; Ross, J.W.; Beath, C.; Mocker, M.; Moloney, K.G.; Fonstad, N.O. How Big Old Companies Navigate Digital Transformation. MIS Quart. Exec. 2017, 16, 197-213. [CrossRef]

44. Leng, J.; Ruan, G.; Jiang, P.; Xu, K.; Liu, Q.; Zhou, X.; Liu, C. Blockchain-Empowered Sustainable Manufacturing and Product Lifecycle Management in Industry 4.0: A Survey. Renew. Sustain. Energy Rev. 2020, 132, 1-20. [CrossRef]

45. Esmaeilian, B.; Sarkis, J.; Lewis, K.; Behdad, S. Blockchain for the Future of Sustainable Supply Chain Management in Industry 4.0. Resour. Conserv. Recycl. 2020, 163,1-15. [CrossRef]

46. Bohnsack, R.; Pinkse, J.; Kolk, A. Business Models for Sustainable Technologies: Exploring Business Model Evolution in the Case of Electric Vehicles. Res. Policy 2014, 43, 284-300. [CrossRef]

47. Demartini, M.; Evans, S.; Tonelli, F. Digitalization Technologies for Industrial Sustainability. Procedia Manuf. 2019, 33, 264-271. [CrossRef]

48. Weersink, A.; Fraser, E.; Pannell, D.; Duncan, E.; Rotz, S. Opportunities and Challenges for Big Data in Agricultural and Environmental Analysis. Annu. Rev. Resour. Econ. 2018, 10, 19-37. [CrossRef]

49. Deloitte. Global Enabling Sustainability Initiative Digital with Purpose: Delivering a SMARTer 2030; Global Enabling Sustainability Initiative: Brussels, Belgium, 2019.

50. Fitzgerald, M.; Kruschwitz, N.; Bonnet, D.; Welch, M. Embracing Digital Technology: A New Strategic Imperative. Sloan Manag. Rev. 2014, 55, 1-22.

51. Andriole, S.J. Five Myths About Digital Transformation. Sloan Manag. Rev. 2017, 58, 22.

52. Liere-Netheler, K.; Packmohr, S.; Vogelsang, K. Drivers of Digital Transformation in Manufacturing. In Proceedings of the 51st Hawaii International Conference on System Sciences (HICSS 2018), Waikoloa Village, HI, USA, 3-6 January 2018.

53. Morakanyane, R.; Grace, A.; O’Reilly, P.; Pucihar, A.; Borštnar, M.K.; Kittl, C.; Ravesteijn, P.; Clarke, R.; Bons, R. Conceptualizing Digital Transformation in Business Organizations: A Systematic Review of Literature. In Proceedings of the Bled eConference, Bled, Slovenia, 18-21 June 2017. [CrossRef]

54. Remane, G.; Hanelt, A.; Nickerson, R.C.; Kolbe, L.M. Discovering Digital Business Models in Traditional Industries. J. Bus. Strat. 2017, 38, 41-51. [CrossRef]

55. Verhoef, P.C.; Broekhuizen, T.; Bart, Y.; Bhattacharya, A.; Dong, J.Q.; Fabian, N.; Haenlein, M. Digital Transformation: A Multidisciplinary Reflection and Research Agenda. J. Bus. Res. 2021, 122, 889-901. [CrossRef]

56. Roth, S.; Dahms, H.F.; Welz, F.; Cattacin, S. Print Theories of Computer Societies. Introduction to the Digital Transformation of Social Theory. Technol. Forecast. Soc. Chang. 2019, 149, 1-6. [CrossRef]

57. Lucas, J.H.C.; University of Maryland; Agarwal, R.; Clemons, E.K.; El Sawy, O.A.; Weber, B.; University of Pennsylvania; University of Southern California; University of Delaware. Impactful Research on Transformational Information Technology: An Opportunity to Inform New Audiences. MIS Q. 2013, 37, 371-382. [CrossRef]

58. Vial, G. Understanding Digital Transformation: A Review and a Research Agenda. J. Strat. Inf. Syst. 2019, 28, 118-144. [CrossRef]

59. Gong, C.; Ribiere, V. Developing a Unified Definition of Digital Transformation. Technovation 2021, 102, 1-17. [CrossRef]

60. ElMassah, S.; Mohieldin, M. Digital Transformation and Localizing the Sustainable Development Goals (SDGs). Ecol. Econ. 2019, 169, 1-10. [CrossRef]

61. Holzinger, A.; George, G.; Merrill, R.K.; Schillebeecks, S.J.D. Digital Sustainability and Entrepreneurship: How digital Innova-tions Are Helping to Tackle Climate Change and Sustainable Development. Entrep. Theory Pract. 2020, 23, 999-1027. [CrossRef]

62. Weippl, E.; Tjoa, A.M.; Kieseberg, P. Digital Transformation for Sustainable Development Goals (SDGs)—A Security, Safety and Privacy Perspective on AI. In International Cross-Domain Conference for Machine Learning and Knowledge Extraction; Springer: Cham, Switzerland, 2021.

63. Jones, P.; Wynn, M. The Leading Digital Technology Companies and Their Approach to Sustainable Development. Sustainability 2021, 13, 6612. [CrossRef]

64. The Role of Artificial Intelligence in Achieving the Sustainable Development Goals. Available online: https://www.nature.com/ articles/s41467-019-14108-y (accessed on 10 October 2021). 
65. Nidumolu, R.; Prahalad, C.K.; Rangaswami, M.R. Why Sustainability is Now the Key Driver of Innovation. Harv. Bus. Rev. 2009, $87,57-64$.

66. Coronella, S.; Caputo, F.; Leopizzi, R.; Venturelli, A. Corporate Social Responsibility in Economia Aziendale Scholars' Theories. Meditari Account. Res. 2018, 26, 640-656. [CrossRef]

67. Eccles, R.G.; Krzus, M.P. One report: Integrated Reporting for a Sustainable Strategy; John Wiley \& Sons: Hoboken, NJ, USA, 2010.

68. Gray, B.; Stites, J.P. Sustainability through Partnerships. Capitalizing on Collaboration; Network for Business Sustainability: Ontario, ON, Canada, 2013.

69. Joyce, A.; Paquin, R.L. The Triple Layered Business Model Canvas: A Tool to Design More Sustainable Business Models. J. Clean. Prod. 2016, 135, 1474-1486. [CrossRef]

70. Pizzi, S.; Caputo, F.; Venturelli, A.; Adamo, S. Achieving Sustainable Development Goals through Non-Financial Regulation. First Insights from the Transposition of Directive 95/2014/EU in Italy. In Corporate Social Responsibility. Theoretical Analysis and Practical Implications; FrancoAngeli: Milano, Italy, 2020; pp. 11-13. ISBN 9788835103752.

71. Stubbs, W.; Cocklin, C. Conceptualizing a "Sustainability Business Model". Organ. Environ. 2008, 21, 103-127. [CrossRef]

72. Lüdeke-Freund, F. Towards a Conceptual Framework of Business Models for Sustainability. In Proceedings of the Knowledge Collaboration \& Learning for Sustainable Innovation, 14th European Roundtable on Sustainable Consumption and Production (ERSCP) con-ference and the 6th Environmental Management for Sustainable Universities (EMSU) Conference, Delft, The Netherlands, 25-29 October 2010; pp. 1-28.

73. Schaltegger, S.; Hansen, E.G.; Lüdeke-Freund, F. Business Models for Sustainability. Organ. Environ. 2016, 29, 3-10. [CrossRef]

74. Fiorentino, R.; Grimaldi, F.; Lamboglia, R.; Merendino, A. How Smart Technologies Can Support Sustainable Business Models: Insights from an Air Navigation Service Provider. Manag. Decis. 2020, 58, 1715-1736. [CrossRef]

75. Parida, V.; Sjödin, D.; Reim, W. Reviewing Literature on Digitalization, Business Model Innovation, and Sustainable Industry: Past Achievements and Future Promises. Sustainability 2019, 11, 391. [CrossRef]

76. Can Digitalization Favour the Emergence of Innovative and Sustainable Business Models? A Qualitative Exploration in the Automotive Sector. Available online: https:/ / www.emerald.com/insight/content/doi/10.1108/JSMA-02-2021-0033/full/pdf? title=can-digitalization-favour-the-emergence-of-innovative-and-sustainable-business-models-a-qualitative-exploration-inthe-automotive-sector (accessed on 10 October 2021).

77. Tabira, Y.; Otieno, F.X. Integration and Implementation of Sustainable ICT-Based Education in Developing Countries: Low-Cost, En Masse Methodology in Kenya. Sustain. Sci. 2017, 12, 221-234. [CrossRef]

78. Cheng, B.; Ioannou, I.; Serafeim, G. Corporate Social Responsibility and Access to Finance. Strat. Manag. J. 2014, 35, 1-23. [CrossRef]

79. Qiu, Y.; Shaukat, A.; Tharyan, R. Environmental and Social Disclosures: Link with Corporate Financial Performance. Br. Account. Rev. 2016, 48, 102-116. [CrossRef]

80. Haque, F. The Effects of Board Characteristics and Sustainable Compensation Policy on Carbon Performance of UK firms. Br. Account. Rev. 2017, 49, 347-364. [CrossRef]

81. Bannier, C.E.; Bofinger, Y.; Rock, B. Doing Safe by Doing Good: ESG Investing and Corporate Social Responsibility in the U.S. and Europe; CFS Working Paper Series 621; Center for Financial Studies (CFS): Frankfurt, Germany, 2019.

82. Papoutsi, A.; Sodhi, M.S. Does Disclosure in Sustainability Reports Indicate Actual Sustainability Performance? J. Clean. Prod. 2020, 260, 1-10. [CrossRef]

83. Hossnofsky, V.; Junge, S. Does the Market Reward Digitalization Efforts? Evidence From Securities Analysts' Investment Recommendations. J. Bus. Econ. 2019, 89, 965-994. [CrossRef]

84. Ricci, F.; Scafarto, V.; Ferri, S.; Tron, A. Value Relevance of Digitalization: The Moderating Role of Corporate Sustainability. An Empirical Study of Italian Listed Companies. J. Clean. Prod. 2020, 276, 123282. [CrossRef]

85. Morris, R. Computerized Content Analysis in Management Research: A Demonstration of Advantages \& Limitations. J. Manag. 1994, 20, 903-931. [CrossRef]

86. Cho, T.S.; Hambrick, D.C. Attention as the Mediator Between Top Management Team Characteristics and Strategic Change: The Case of Airline Deregulation. Organ. Sci. 2006, 17, 453-469. [CrossRef]

87. Meek, G.K.; Roberts, C.B.; Gray, S.J. Factors Influencing Voluntary Annual Report Disclosure by US, UK and Continental European Multinational Corporations. J. Int. Bus. St. 1995, 26, 555-572. [CrossRef]

88. Lan, Y.; Wang, L.; Zhang, X. Determinants and Features of Voluntary Disclosure in the Chinese Stock Market. China J. Account. Res. 2013, 6, 265-285. [CrossRef]

89. Modaress, A.; Alimohamadpour, A.; Rahimi, S. Determinants of Corporate Voluntary Disclosure in the Annual Reports: The Study of Tehran Stock Exchange. Int. J. Manag. Human. Sci. 2014, 3, 2401-2407.

90. Scaltrito, D. Voluntary Disclosure in Italy. EuroMed J. Bus. 2016, 11, 272-303. [CrossRef]

91. Field, A. Discovering Statistics using SPSS, 3rd ed.; Sage: London, UK, 2009.

92. Kasali, A.O.; Raghunath, A.; Kehinde, S.D. Determination of Lag Threshold on the Measure of Collinearity. J. Stat. Econ. Met. 2014, 115-132.

93. Kolmogoroff, A. Confidence Limits for an Unknown Distribution Function. Ann. Math. Stat. 1941, 12, 461-463. [CrossRef]

94. Smirnov, N. Table for Estimating the Goodness of Fit of Empirical Distributions. Ann. Math. Stat. 1948, 19, 279-281. [CrossRef]

95. Shapiro, S.S.; Wilk, M.B. Approximations for the Null Distribution of the W Statistic. Technometrics 1968, 10, 861-866. [CrossRef] 
96. Shapiro, C.; Varian, H.R. Information Rules: A Strategic Guide to the Network Economy; Harvard Business School Press: Boston, MA, USA, 1999.

97. European Commission Digital Economy and Society Index (DESI) 2020. Available online: https:/ /digital-strategy.ec.europa.eu/ en/policies/desi (accessed on 2 August 2021).

98. Venkatraman, N. IT-Enabled Business Transformation: From Automation to Business Scope Redefinition. Manag. Rev. 1994, $35,73-87$.

99. Amit, R.; Zott, C. Creating Value Through Business Model Innovation. Manag. Rev. 2012, 53, 41-49.

100. Iansiti, M.; Lakhani, K.R. Digital Ubiquity: How Connections, Sensors, and Data are Revolutionizing Business. Intergovernmental Plan on Climate Change. Harv. Bus. Rev. 2014, 92, 90-99.

101. Lerch, C.; Gotsch, M. Digitalized Product-Service Systems in Manufacturing Firms: A Case Study Analysis. Res. Manag. 2015, 58, 45-52. [CrossRef]

102. Nambisan, S.; University of Wisconsin-Milwaukee; Lyytinen, K.; Majchrzak, A.; Song, M.; Case Western Reserve University; University of Southern California; Xi'an Technological University. Digital Innovation Management: Reinventing Innovation Management Research in a Digital World. MIS Q. 2017, 41, 223-238. [CrossRef]

103. Nambisan, S.; Wright, M.; Feldman, M. The Digital Transformation of Innovation and Entrepreneurship: Progress, Challenges and Key Themes. Res. Policy 2019, 48, 1-9. [CrossRef]

104. Hänninen, M.; Smedlund, A.; Mitronen, L. Digitilization in Retailing: Multi-Sided Platforms as Drivers of Industry Transformation. Balt. J. Manag. 2018, 13, 37-43.

105. Brousseau, E.; Penard, T. The Economics of Digital Business Models: A Framework for Analyzing the Economics of Platforms. Rev. Netw. Econ. 2007, 6. [CrossRef]

106. Chang, J.; Li, H.; Sun, B. Matching Knowledge Suppliers and Demanders on a Digital Platform: A Novel Method. IEEE Access 2019, 7, 21331-21342. [CrossRef]

107. Vandermerwe, S.; Rada, J. Servitization of Business: Adding Value by Adding Services. Eur. Manag. J. 1988, 6, 314-324. [CrossRef]

108. Vargo, S.L.; Lusch, R.F. Service-Dominant Logic: Continuing the Evolution. J. Acad. Mark. Sci. 2008, 36, 1-10. [CrossRef]

109. Johnson, M.W.; Christensen, C.M.; Kagermann, H. Reinventing your Business Model. Harv. Bus. Rev. 2008, 86, 57-68.

110. Demil, B.; Lecocq, X. Business Model Evolution: In Search of Dynamic Consistency. Long Range Plan. 2010, 43, 227-246. [CrossRef]

111. Belvedere, V.; Grando, A.; Bielli, P. A quantitative Investigation of the Role of Information and Communication Technologies in the Implementation of a Product-Service System. Int. J. Prod. Res. 2013, 51, 410-426. [CrossRef]

112. Weill, P.; Woerner, S.L. Optimizing your Digital Business Model. IEEE Eng. Manag. Rev. 2015, 43, 123-131. [CrossRef]

113. Vendrell-Herrero, F.; Wilson, J.R. Servitization for Territorial Competitiveness: Taxonomy and Research Agenda. Compet. Rev. 2016, 27, 2-11. [CrossRef]

114. Vendrell-Herrero, F.; Bustinza, O.F.; Parry, G.; Georgantzis, N. Servitization, Digitization and Supply Chain Interdependency. Ind. Mark. Manag. 2017, 60, 69-81. [CrossRef]

115. Foss, N.J.; Saebi, T. Fifteen Years of Research on Business Model Innovation. J. Manag. 2017, 43, 200-227. [CrossRef]

116. Gandia, R.; Parmentier, G. Optimizing Value Creation and Value Capture with a Digital Multi-Sided Business Model. Strat. Chang. 2017, 26, 323-331. [CrossRef]

117. Martín-Peña, M.L.; Díaz-Garrido, E.; Sánchez-López, J.M. The Digitalization and Servitization of Manufacturing: A Review on Digital Business Models. Strat. Chang. 2018, 27, 91-99. [CrossRef]

118. Frank, A.G.; Mendes, G.; Ayala, N.F.; Ghezzi, A. Servitization and Industry 4.0 Convergence in the Digital Transformation of Product Firms: A Business Model Innovation Perspective. Technol. Forecast. Soc. Chang. 2019, 141, 341-351. [CrossRef]

119. Kohtamäki, M.; Parida, V.; Oghazi, P.; Gebauer, H.; Baines, T. Digital Servitization Business Models in Ecosystems: A Theory of the Firm. J. Bus. Res. 2020, 104, 380-392. [CrossRef]

120. Sjödinab, D.; Paridaabc, V.; Kohtamäkiabc, M.; Wincentde, J. An Agile Co-Creation Process for Digital Servitization: A Micro-Service Innovation Approach. J. Bus. Res. 2020, 112, 478-491. [CrossRef] 